\title{
Hinweis für Leser / Note for Readers
}

Die Schriften Ludwig Wittgensteins werden in den Wittgenstein-Studien mit einheitlichen Siglen zitiert, die der von Alois Pichler und Michael Biggs zusammengestellten Bibliographie der deutsch- und englischsprachigen WittgensteinAusgaben (erschienen in Wittgenstein-Studien 02/2011, 249-286) entnommen werden können. Diese Bibliographie kann auch unter der Adresse www.ilwg.eu als PDF-Datei heruntergeladen werden.

The writings of Ludwig Wittgenstein are cited in Wittgenstein-Studien using the uniform citation keys, which can be found in the Bibliographie der deutschund englischsprachigen Wittgenstein-Ausgaben / Bibliography of German and English Editions of Wittgenstein (published in Wittgenstein-Studien 02/2011, 249286), compiled by Alois Pichler and Michael Biggs. This bibliography can also be downloaded as a PDF file at www.ilwg.eu. 
